\title{
Programs and Parties: Rethinking Electoral Competition Through Analysis of Brazilian 'Grotões'*
}

\begin{abstract}
Nara Salles
https://orcid.org/0000-0002-2681-8412

Universidade do Rio de Janeiro, Rio de Janeiro, Rio de Janeiro, Brazil

The 'salience theory of party competition' moves on from the 'programmatic paradox' imposed by the classic Downsian proximity model and demonstrates that parties compete with each other by means of the emphases they give to certain issues. They do this by leveraging their government programs to shape voter preferences that form an innate component of the electoral process. This phenomenon has been neglected in a Brazil supposedly dominated by weak parties, personality politics and clientelism. This scenario is most pronounced at a local level, particularly in the country's so-called 'grotões' where the electorate is motivated by a desire to meet its basic needs, which has the effect of strengthening client relationships with political candidates. In these areas, the relevance of government programs reaches its nadir. The aim of this article is to investigate this phenomenon in Brazilian municipalities with the lowest Municipal Human Development Index (MHDI) scores. The study is underpinned by two hypotheses: 01. that government programs form an integral component of electoral competition in Brazil and 02. that they are formulated along partisan lines. In order to test these hypotheses, I have performed an analysis of the government programs registered by mayoral candidates running in 2012 and 2016, using the text analysis method that estimates political positions through word frequency (Wordfish). The results fully confirm the first hypothesis but only partly confirm the second.
\end{abstract}

Keywords: Party alignment; Brazil; electoral competition; government programs; wordfish.

http://dx.doi.org/10.1590/1981-3821201900020003/

For data replication, see: https://doi.org/10.7910/DVN/RFRIEV

This publication is registered under a CC-BY Licence.

${ }^{*}$ My thanks to Fernando Guarnieri, to the researchers at Doxa (Institute of Social and Political Studies/ Universidade do Rio de Janeiro) and to the anonymous reviewers at BPSR for their useful comments in previous versions of this article. 
lthough government programs may be important, if not central to many
party or electoral competition theories applied to democracies, they have been neglected by the literature on Brazilian elections. This oversight can be attributed to the widely held belief that Brazil's political scene is made up of weak parties and that personality politics and relational practices such as clientelism hold sway. For such authors as Ames (2003) and Mainwaring (1991, 1999), this perspective is associated with the current open-list proportional representation system, which favors political individualism. Such a diagnosis also follows quite naturally in the light of the fact that historical continuities have been unable to replace the country's traditional political elites and their archaic political practices (HAGOPIAN, 1996). This interpretation can also flow from an understanding of the inequalities experienced by a large proportion of voters and municipalities in Brazil (HUNTER and POWER, 2008; LEAL, 1975; MAINWARING, 1991). Whatever the justification, the concept that there are cohesive parties in Brazil's political scene is rejected, and it is assumed that political competition is determined by the relational ties that result from the poverty and low level of education of the country's citizens.

In 2009, however, President Luís Inácio Lula da Silva sanctioned Law noㅜ 12,034 , which required that all candidates running for executive office in Brazil register their political party programs with the Higher Electoral Court. This new requirement alongside recent efforts to demonstrate the importance of government programs (BABIRESKI, 2014; JORGE et al., 2018; KITSCHEL et al., 2010, OLIVEIRA, 2011; TAROUCO, 2011; TAROUCO and MADEIRA, 2013) - puts us in a position to resume the debate on electoral competition in Brazil from a fresh perspective.

The aim of this study is therefore to investigate the programmatic dimension in Brazilian elections and the extent to which they are formulated along partisan lines. Since the classical perspective considers municipalities to be the locus par excellence of clientelistic practices and archaic traditionalism (AMES, 2003; ANDRADE and SANTOS, 2004; AVELAR and WALTER, 2008; LEAL, 1975; SCHWARTZMAN, 1975), these will be the focus of this study. Its main argument is that voters in Brazil's so-called 'grotões' are seeking to fulfil their most basic needs, and that this reinforces their clientelistic relationship with candidates; whereas voters in more highly developed regions are more programmatically oriented 
(AMES, 2003; KITSCHELT et al., 2010; SCHWARTZMAN, 1975). It is important to point out that the intention here is not to determine the full nature of electoral competition or its determinants at a local level, but rather to seek out the programmatic dimension where it is least likely to be found. If found it is, one could reasonably conclude that government programs, like so many other elements, are integral components of Brazilian electoral competition.

In order to do this, I have performed an analysis of the government programs registered by mayoral candidates in the 2012 and 2016 elections in Brazilian municipalities with very low Municipal Human Development Index (MHDI) scores according to the 2010 Brazilian Atlas of Human Development. The sample consists of 32 municipalities with populations of between 5,000 and 50,000, located in Brazil's North and Northeast. Documents were analyzed using the text analysis method developed by SLAPIN and PROKSCH (2008) to estimate party political positions based on word frequencies in texts (Wordfish). Cases where differences exist between opponents' programs in the same municipality confirm my main hypothesis that government programs play a role in electoral competition in Brazil. Where this is the case, I go on to test my secondary hypothesis that government programs follow party alignments across municipalities. It is important to point out that evidence to support the existence of government programs does not necessarily imply that policy motivates actors. From the point of view of this study, there would be no contradiction in concluding that parties and candidates leverage government programs for the sole purpose of electoral competition.

This article is divided into six parts. The first comprises a discussion the deployment of government programs as an electoral competition strategy. The second and third parts provide an overview of the discussion in relation to elections in Brazil, demonstrating how this element is not taken into account and presenting recent studies that have discussed it. The fourth section provides a description of the methodology used, and the fifth describes and comments on the results of the analysis. Finally, in the conclusion, I argue that the time has come to fill in the lacunae on the subject of government programs and replace the current monochromatic view of elections in Brazil, by developing a more complex interpretation of Brazil's political actors and the structures of their preferences. 


\section{The current debate on government programs and party strategies}

The classical theory of party competition views government programs as the central element in the establishment of preferences. For Downs (1957a, 1957b), parties - rational actors that seek solely to maximize votes - propose policies in order to win elections. For their part, voters - also rational - seek to maximize utility by selecting the party whose positions are most closely aligned with their own. Because they want to reach the largest possible number of voters, party tend to converge on policy positions seen as attractive to the 'median voter'. In this sense, as elections are defined in terms of policies - 'programs' in this study - the Downsian proximity model leads to an inescapable 'programmatic paradox', whereby the general trend is for policies to converge rather than compete - at least in programmatic terms.

However, according to Grofman (2004), the rupture of just one (or more) of Downs' main premises results in non-convergence between parties, and opens up the possibility of a programmatic contest. One of the most bruising criticisms of the classical proximity model was made by Stokes (1963) in relation to the matter of its unidimensionality. He believed there was an empirical discrepancy in Downsian analysis, as the electorate' preferences are not distributed exclusively along a leftright continuum, but according to a range of issues that vary in relevance over time. Unlike the inevitable formation of preferences exogenous to electoral contests, as described by the Downsian model, Stokes (1963) believes that preference formation occurs intrinsically. For this reason, one of the most important tasks for parties during elections is to make strategic use of latent elements in an electoral contest. He points out that:

Political fortunes are made and lost according to the ability of party leaders to sense what dimensions will be salient to the public as it appraises the candidates and party records. [...] the skills of political leaders who must maneuver for public support in a democracy consist partly in knowing what issue dimensions are salient to the electorate or can be made salient by suitable propaganda (STOKES, 1963, p. 372).

The idea that an electoral contest is shaped through various distinct dimensions that can be strategically manipulated by parties is the basic assumption 
of 'salience theory of party competition', one of the main theories proposed for the study of elections in terms of their government program component (BUDGE and FARLIE, 1983). Seen from to this perspective, one of the ways that parties compete is through the emphasis they give to certain areas and public policy proposals. For example, some gain votes by using strong prior associations with specific issues created over the long term, as is the case for socialist and labor parties. Others use the electoral campaign period itself to establish short-term dominance in terms of certain issues within the electoral timetable itself. Parties can also use both strategies simultaneously during the same election.

In a pioneering study, Robertson (1976) noticed that a small number of phrases assumed positions favorable or contrary to 22 specific themes in British manifestos between 1922 and 1974. In his study, he identified a characteristic common to all party platforms: parties could be aligned according to 'selective emphasis' on different policies as opposed to direct confrontation. The author then calculated how many times a policy category was mentioned in a given program in relation to the others, and developed the fundamental idea behind salience theory: 'parties define their policies by emphasizing certain subjects in their programs to the detriment of others'.

Budge and Farlie (1983) subsequently used these studies as the basis for a more systematic formulation of salience theory. In a dialog with Campbell et al. (1960), they demonstrated that issues do not have an impact on immediate voting decisions alone, but also on the formation of party identification. Furthermore, they argued that any explanation for voting decisions resides, explicitly or implicitly, in party behavior, as it is political parties that simplify the complex political universe through their public policy offers as embodied in their government programs. Therefore, "[...] the way electors decide to vote stems directly from the way parties approach them" (BUDGE and FARLIE, 1983, p. 23).

If government programs are the main vehicle for parties to communicate their policies and positions to the electorate, Budge and Farlie (1983) found evidence partly corroborating the idea that this takes place through the wider debate between candidates on why their policies provide the best solutions for the main issues of the day. From this observation, they reformulated the fundamental importance of party behavior in elections, in which 'selective emphasis' is the main 
strategy as opposed to 'direct confrontation' between opponents. This observation can be summed up in the concept of 'issue ownership', which is the idea that parties 'possess' certain issues (BUDGE and FARLIE, 1983; SIO and WEBER, 2014). This implies that party strategies follow the belief that voters can associate a specific party with good or bad performance in a specific area. Therefore, the main issues ascribed to a party also serve as a sort of informational shortcut for voters, with proposals and positions simplifying and emphasizing aspects of the political scene.

Salience theory is the main alternative to the 'programmatic paradox' imposed by Downs (1957a, 1957b), as it is specifically associated with studies into government programs and involves its own method of analysis (which will be discussed in more detail below), although there are other studies reinforcing the importance of issues in elections. The 'party activism model' (ALDRICH, 1983), 'directional model' (RABINOWITZ and MAcDONALD, 1989) and 'discount model' (GROFMAN, 1985) also demonstrate that there are incentives for parties to hold distinct positions. Wittman (1983) and Alesina (1988) have also added parties' longterm political motivations to the debate, which show possible commitments to internal agendas and their voters.

Furthermore, a response can be inferred to the common argument that few voters actually read government programs, especially in Brazil. This is not just a consequence of the aforementioned allegation that voters' needs can be easily met through clientelistic practices, but is also a result of the high levels of illiteracy in Brazilian municipalities. Nonetheless, the shaping process for saliences is mediated, and the various media that do not require literacy skills are used to inform voters of proposals, including the various forms of mass communication, for example (BUDGE, 1987). Government programs are therefore of substantial importance in political contests.

\section{Electoral competition in Brazil and the omission of programmatic dimension}

Despite government programs being one of the determining elements in electoral competition, they are consistently regarded as insignificant in Brazilian elections. Many authors believe that this omission is based on the institutional framework stipulated by the 1988 Constitution, upholding the country's presidentialism, 
federalism and its open-list proportional representation system (AMES, 2003; MAINWARING, 1991, 1999). Mainwaring (1991), for example, states that current electoral legislation reinforces the individualistic behavior of politicians, resulting in what he refers to as the 'unique underdevelopment of Brazilian parties'. This is because the open-list proportional representation system removes parties' control over their candidates, offering the electorate the option to make individual choices. In this sense, the capacity of a candidate to be elected to office would depend more on their ability to win votes and compete with alternative candidates within the same party. According to Mainwaring (1991), Brazilian electoral legislation has institutionalized "[...] a system that encourages weak party commitment, solidarity, discipline, and cohesiveness" (MAINWARING, 1991, p. 16).

Despite this pessimistic diagnosis, the author emphasizes that institutional frameworks can always be changed. He rightly argues that politicians are not just products of the systems in which they operate: they also have the power to shape these to some extent. Brazil's disadvantage, therefore, is also the result of the choices of its political elites, which have conveniently opted to maintain the individualistic and non-party-based rules.

The desire to create effective parties is not sufficient for such parties to emerge, but it is indispensable. This desire does not exist in Brazil. Politicians have attempted to prevent more effective parties from emerging, believing that party loyalty and more disciplined parties would impose authoritarian constrains and limit their ability to attend to their clienteles. With loosely organized parties, politicians are freer to attend to their own clienteles without being bound to 'programmatic concerns' or organizational commitments (MAINWARING, 1991, p. 39, my emphasis).

Thus, in the absence of effective parties, Brazilian politics has been supposedly occupied by the state, political elites, their economic allies and the armed forces. As a consequence, personality politics, clientelism and individualist styles of representation have been allegedly strengthened, while mechanisms of accountability are completely limited. Therefore, Brazil appears to be destined to particularly perverse associations between its representation and clientelism.

Hagopian (1996) highlights the continued presence of the traditional elites in contemporary Brazilian politics. She believes that the end of the country's military 
dictatorship in and of itself did not - and could never - guarantee effective democracy. This is because despite obvious changes to the party system, the political elite remained in power and continued its practices from both the authoritarian regime and the period preceding 1964. Therefore, clientelism and regionalism remain important factors to be considered in order to understand Brazil: "Party positions on issues are sacrificed systematically to the particularistic calculations of a closed elite, and weak parties suit a restricted democracy" (HAGOPIAN, 1996, p. 281).

However, notwithstanding the significance of electoral rules and historical continuities, the most important factor for the purposes of this study are the social inequalities within the electorate that lead to the same result. Mainwaring (1992-93) argued that profound inequalities in Brazil result in a political system that excludes the participation of the masses. Accordingly, extreme poverty and the rudimentary political awareness of large sections of the population have condemned the populace to clientelistic dependency on politicians and the state apparatus. The population's skepticism vis-à-vis politics and its inability to understand and adequately apply labels of left and right led him to the following conclusion: "A vast segment of the population votes according to extremely diffuse images or for personal favors. [...] The population is receptive to individualistic and populist campaigns; these predilections in turn favor non-ideological, populist parties" (MAINWARING, 1992-93, p. 694).

Gay (1998) points out that this system is characterized by a sort of premodern clientelism that is blamed for all of the country's ills, ranging from cycles of inflation to democratic collapses, disorganization and the marginalization of the country's poor. The author states that "Most scholars agree that the extreme vulnerability of perhaps the majority of the Brazilian population compels it to literally 'sell' its votes to candidates for public office in exchange for the delivery or simply the promise of patronage" (GAY, 1998, p. 11).

Another author on the same theme, Leal (1975, p. 258), considers that social circumstances such as "the poverty of the people, their civic and intellectual backwardness" can reinforce clientelistic practices. Mainwaring is in agreement (1991), stating that Brazilians who live in poverty are not able to effectively participate in the political system. Possessing what the author describes 
as 'rudimentary political consciousness', Brazil's poor are apparently destined to both depend on clientelistic mediations to ensure their survival and incessantly feed back into this system.

Another important perspective is that the rewards obtained through clientelistic practices are inferior and unworthy of votes. This viewpoint considers both the patron and the Brazilian electorate to be backwards. From this point of view, it would make no sense to fight elections using any form of programmatic dimension. Gay (1998) summarizes that: "Thus, for many, clientelism makes it extremely difficult for voters to organize their thoughts in terms of a left-right or any other continuum and places tremendous strain on what is often referred to as ideological or programmatic politics" (GAY, 1998, p. 11).

It is important to note that the debate on the power of clientelism in Brazil is structured, whether implicitly or explicitly, from a 'political development' perspective, which distinguishes 01 . traditional societies, 02 . societies in transition, and 03. politically developed societies (AVELINO FILHO, 1994). Indeed, according to the analyses presented, Brazil has overcome the first stage, characterized by its traditional so-called 'parties of notables', dependence on the personal resources of patrons and affective relationships. It is currently in the transitional phase, in which clientelistic relationships are predominantly formed with the state but starting to take on the market characteristics, becoming a "product of the maladjustment between the social structure and the political system" (AVELINO FILHO, 1994, p. 226, our translation). Seemingly, Brazil's political development was not accompanied by a strengthening of the universal and impersonal institutions characteristic of developed societies. We have been condemned as backward thanks to a faulty understanding of political evolution.

The view that local politics, especially in smaller municipalities, is by definition the locus of political practices that are considered archaic - such as patron-client exchange, vote-rigging, traditionalism, 'mandonism', and clientelism originated in the work of Leal (1975). Through the concept of 'coronelism', the author describes a method of exchange between the central state and the landowning classes in decline. In this system, which demonstrates how the structuring of power relations began in the municipalities of Brazil's First Republic, 
governors depended on the electoral support of coronels in order to win votes, who in turn needed public power in order to obtain various resources.

Despite this important contribution, Kerbauy (2000) and Limongi (2012) have already convincingly demonstrated that the author's analysis is obsolete in relation to the analysis of electoral competition in contemporary Brazil. Kerbauy (2000) believes that institutional changes imposed by the military regime alongside the urban transformations experienced by the country since 1950 have brought about the death of the coronels. Limongi (2012) argues that a different interpretation of Leal (1975) can lead to the conclusion that the elections are anything but a farce. On the contrary: they effectively regulate political conflict. Considering the above, there is no need to get into the specifics of coronelism.

For the purposes of this study, it is enough to demonstrate how municipalities were created as the basis for a system of political traditionalism through the ideas developed by the author. According to Kerbauy (2000), this occurs due to the economic explanation that classical studies on local power in Brazil attribute to political phenomena. This has generated differences between political practice in small rural municipalities and larger capitals in terms of traditionalism (DINIZ, 1982). Incorporating Leal's observation that "in the countryside, the rural element predominates over the urban" (LEAL, 1975, p. 35), the literature perpetuates the perspective that the urbanization process has transformed the political context in the state capitals, with traditionalism persisting in rural areas.

There are other studies that also discuss this relationship. Ames (2003) states that clientelistic ties are stronger in the country's so-called 'grotões', where voters have more basic needs that are therefore more easily met through clientelistic practices. Schwartzman (1975) points out that programmatic conduct should probably increase to the same extent that Brazil's regions develop.

Although coronelism in its original form has been eradicated, some argue that traditional solidarity has transformed into new types of clientelism (ANDRADE and SANTOS, 2004; AVELAR and WALTER, 2008; KERBAUY, 2000). The divide between rural and urban municipalities, however, has persisted. AVELAR and WALTER (2008, p. 104, our translation) state that: "in more 'peripheral' regions with strong local and regional power, elections are more predictable, especially 
considering that there are no solid differences between parties from an ideological point of view. Regional oligarchs are still a political reality". In agreement with Hagopian (1996), the authors concluded that on one hand, there is an overall permanence of Brazil's historically-constructed political structure. On the other, they do not deny that changes have been imposed on the nature of political competition, above all through processes of urbanization. Nevertheless, they state that: "Where there are changes, they reach less industrialized and urbanized locations much more slowly [...]" (AVELAR and WALTER, 2018, p. 109, our translation).

It can be noted from this that if government programs are not even included in the debate on electoral competition in Brazil, this should be expected to be even farther from the country's municipalities, particularly its 'grotões'. Therefore, as mentioned above, this will not be an investigation into specific determinants involved in competition or the party system at a local level. The aim of this study is to seek the element that is missing from this debate - government programs to electoral competition in Brazil - in the places it is least likely to be found.

\section{The bases for a new perspective}

Despite this identified omission, recent initiatives highlight the importance of government programs in Brazil. One highlight is the work by Kitschelt et al. (2010), who dedicated themselves to investigating the 'programmatic structuration' of parties in 12 democracies in Latin America. They argue that despite the traditional image of the predominance of clientelistic ties, the 'programmatic structuration' of parties can be conceived of and identified in this region. This process consists of 'programmatic coordination', or the use of labels, to organize coherently the political alternatives that define the competitive space of democratic elections.

Using four indicators - programmatic partisan cleavages, programmatic content using left-right semantics, party ideological cohesiveness and intraparty cohesiveness in relation to issues - the authors analyzed 12 democracies up to the end of the 1990s and distributed them along a continuum from high to low programmatic structuring. Despite identifying low levels of programmatic structuration in Brazil, they argued that this would not be sufficient to distort the 
differences in programmatic competition established in the region. After all, some programmatic structuration was observed.

Even authors focusing on Brazil's electoral rules have dedicated efforts to investigating government programs. Samuels (1997) identified possible incentives for partisan voting, even in countries where systems are centered on candidates, such as Brazil. Although his analysis focuses on the variation of candidate and not party strategies, party characteristics - including access to candidacies, sources of funding and access to government resources - determine the most individualist or collective strategies. Parties with more control over these variables tend to run candidates that are more dependent on the partisan machine, and therefore develop more collective strategies. On the other hand, candidates tend to adopt more individualist strategies when their party is more independent in relation to the same variables.

It was not the intention of Samuels (1997) - and nor is it mine - to argue that individualist and collective strategies are exclusive, to deny that personalism or particularism exist in Brazil, or to point out that competition is guided exclusively in a partisan way. The author states that even in countries with a strong clientelistic tradition, such as Brazil, Italy and Japan, investing in the partisan component can be cheap and provide large returns, as this can attract the voters who do not benefit from clientele networks or who position themselves programmatically. For these voters, politicians: " can seek votes by both distributing 'physiological' benefits and adopting policy positions, or from a more realistic perspective, taking on a strategy that combines a little of the two orientations, and using a narrative that is both individual and collective" (SAMUELS, 1997, p. 03, our translation).

Even authors that previously highlighted historical continuities and incentives for clientelistic practices in Brazil have developed a more complex panorama in recent studies. Hagopian, Gervasoni and Moraes (2008) emphasize the surge in politicians guided more by their parties or programmatically, replacing previous behavior determined by patronage. On one hand, this is due to the policies and administrative reforms that have been implemented since 1990, which have apparently reduced the scope and resources available for patronage, diminishing the efficiency of electoral strategies of a personal nature. Voters have responded 
favorably to these changes, reinforcing this new process. On the other hand, this new behavior identified in candidates, parties and voters is also related to a polarization phenomenon: the more polarized the party, the greater the loyalty of the electorate to programs and party brands perceived by politicians.

In the light of these results, we need to rethink the determining influence of electoral institutions and shift our focus away from using them to justify an apparent weakness of Brazilian political parties to identifying the causes of stronger, more disciplined, and more programmatically cohesive parties, absent those incentives. (HAGOPIAN, GERVASONI and MORAES, 2008, p. 381).

Claiming there is a programmatic dimension to Brazil's elections does not mean there are no other determining factors involved in this process, such as clientelistic practices and psychological attitudes. On the contrary, this simply addresses this omission in the debate on electoral competition in Brazil and identifies important elements that may not have been considered in previous analyses. After all, as summarized by Figueiredo and Limongi (2002): "The diversity of spatial voting patterns [...] suggests that Brazil's electoral legislation allows politicians to use a range of strategies to get elected and reelected, resorting to the construction of various links with the electorate" (FIGUEIREDO and LIMONGI, 2002, p. 311).

The approach by Gay (1998) goes beyond this, problematizing approaches that reduce even universal policies, such as the Bolsa Família social welfare program, to mere electoral tools or institutionalized mechanisms for buying votes (HUNTER AND POWER, 2008). Therefore, the author rightly states that:

[o]f course [...] there are those who would insist that rights have little to do with the selective and occasional distribution of milk tokens, the paving of roads, the building of schools or the installation of neighborhood sewage systems. And, furthermore, that clientelism, as a strategy that is based on the delivery of such goods and services, undermines any attempt to propagate coherent ideologies or establish programs based on principles of universalism and entitlement. This perspective, I believe, is both simplistic and more to the point, elitist (GAY, 1998, p. 15). 
Beyond this being an oversimplification, political phenomena cannot be satisfactorily understood through social and economic variables alone. Explanatory mechanisms for actors' strategies need to be sought out in the dynamic of the competition itself. Moreover, it is controversial to believe that voters would have lower abilities of programmatic engagement as a result of inequality. After all, are not the poorest and least literate those who are the most dependent, and therefore more interested, in public policy? Would not these voters' daily survival surpass education level or political knowledge in the structuring of their preferences?

All the points discussed above reinforce the need for an investigation into government programs in electoral competition in Brazil, as well as the space to do so. Some recent studies focusing on government programs have already initiated this debate. In a pioneering study, Tarouco (2011) analyzed the founding manifestos of seven parties: the PP, PDT, PT, PTB, PMDB, PFL and PSDB. The method involved the manual codification developed by the Manifesto Research on Political Representation (MARPOR) project ${ }^{1}$, which is the predominant technique used in other studies into government programs in Brazil. By analyzing the content of these manifestos, Tarouco (2011) identified that the main parties in Brazil differ in terms of content, and that the difference in their emphases is not random.

In a later study, however, Tarouco and Madeira (2013) reached a less conclusive diagnosis in an attempt to classify Brazil's political parties along a leftright continuum. Once again, the programmatic documents ${ }^{2}$ provided by the same seven parties were analyzed using the authors' adaptation of the MARPOR codification. With the exception of the documents registered by the PFL in 1995 and 2005 and the PSDB in 2001, all parties were classified on the left of the ideological spectrum. This included, for example, the founding manifesto of the PFL and the PSDB's document for 1988. Therefore, none of the parties was exclusively classified as right wing. In conclusion, the authors simply pointed out that the difference in classification obtained through this program analysis and the normal classification based on legislative behavior may indicate some very real contradictions that are

\footnotetext{
${ }^{1}$ See more on codification categories, domains and procedures at $<$ https://manifestoproject.wzb.eu/datasets $>$. Last accessed on 16/12/2018.

${ }^{2}$ The founding manifestos for parties and directives provided. This did not include government programs.
} 
yet to be explained. They also highlighted the need to improve and adapt the codification used for Brazil.

This positioning of Brazil's political parties on the left was repeated in a study by Babireski (2014) comparing the programs of right wing parties in Brazil, Chile and Uruguay. Using MARPOR codification, the author classified Brazil's DEM and PP parties, Uruguay's PN and the UDI and RN in Chile. Generally speaking, she identified that the Chilean parties were positioned further to the right, the Uruguayan party was more centrist and the Brazilian parties were further to the left. Despite being able to demonstrate differences between them, the author declared the need to refine the methodology used.

Oliveira (2011) identified a positive relationship between class emphasis and the proposal of policies inspired by social democratic values in 15 Latin American countries, also using MARPOR codification. From this classification, he distributed the parties according to four levels of class struggle: high, average to high, average to low and low. The only Brazilian party analyzed, the PT, classified in the average to low category. In relation to social democratic index, the PT emphasized just one liberal theme, while it emphasized four in the social democratic area.

Recently, Jorge et al. (2018) worked specifically on the electoral platforms offered by candidates for the PT and the PSDB during the 2014 presidential elections. Using the MARPOR codification, they tested the hypothesis that the PT held a center-left position and the PSDB held a center-right position on the ideological spectrum. Similarly to Tarouco and Madeira (2013) and Babireski (2014), the authors were unable to corroborate this hypothesis, as they categorized both parties as left wing, with the PSDB to the right of the PT on the same side of the ideological spectrum.

It is important to recognize the importance of investigations into government programs, which is not being included in the debate on electoral competition in Brazil. However, it is clear that these efforts are in the initial stages and are based on a small number of documents provided by a limited group of parties. Furthermore, they all use the same method - the MARPOR codification - which as the authors themselves suggest, is in need of various improvements, as well as 
specific adaptation for the analysis of parties in Brazil. The aim of this study is to help fulfill these requirements.

\section{Methodology}

As mentioned above, the few studies that have analyzed government programs in Brazil used the manual MARPOR codification. Although this method represents a significant contribution, especially in enabling transnational and temporal comparisons, it is associated with a range of limitations that make it unsuitable for the proposed study. Firstly, this codification refers to categories and domains developed for the examination of presidential elections, and secondly, it does not consider the Brazilian context or that of any specific country to which it is applied. Therefore, there is a risk it could lead to fragmented results, by classifying all of Brazil's political parties as left wing, for example (BABIERSKI, 2014; JORGE et al., 2018; TAROUCO and MADEIRA, 2013).

Therefore, this study will use the text analysis model developed by Slapin and Proksch (2008) to estimate political position based on word frequency in documents (Wordfish). Similarly to other methods that can be used to analyze government programs, such as expert survey, manual codification and Wordscores, the selected approach is based on the assumption that by parties' appropriation of words can provide information on their positions on the political spectrum. The model works as follows: a calculation is made of the frequency at which words appear in candidate's programs. It is assumed that the distribution of frequencies originates from a Poisson process:

$$
\begin{gathered}
y_{i j m} \operatorname{Poisson}\left(\lambda_{i j m}\right) \\
\lambda_{i j m}=\exp \left(\alpha_{I}+\psi_{j}+\beta_{j} * \omega_{I}\right)
\end{gathered}
$$

where $y_{i j m}$ is the frequency of word ' $j$ ' in the manifesto of party ' $i$ ' in municipality ' $m$ '; ' $\alpha$ ' is a set of party-municipality fixed effects; ' $\psi$ ' is a set of word fixed effects; ' $\beta$ ' is an estimate of the specific weight of a word capturing the importance of word ' $j$ ' in discriminating between party positions; ' $\omega$ ' is an estimate of the position of party ' $i$ ' in the elections held in municipality ' $m$ '. In this model, the word fixed effects 
control words that are used more frequently than others, and the municipality fixed effects control the parties providing the largest programs in a certain location.

Like any other method, Wordfish has its limitations, particularly its unidimensionality. However, although results are distributed across a single dimension, all of the words in each document are considered, attributing a weight to each word according to its frequency. In addition, Wordfish involves assumptions, estimating that the meaning of words is stable over space and time, for example. On the other hand, this methodology does not require any reference texts, which is the case for Wordscores, (SLAPIN and PROKSCH, 2008).

In this study, Wordfish is used to analyze a 'corpus' made up of 81 government programs produced by the mayoral candidates for the 32 municipalities with the lowest MHDI scores in Brazil ${ }^{3}$ during the 2012 elections $^{4}$, and a further 98 programs produced by candidates running in 2016 in the same locations. It is important to note that this is not a sample of the least developed locations, but comprises all the municipalities classified as having a very low MHDI score in 2010. These were selected because government programs have the lowest probability of successfully integrating into electoral contests in the Brazil's 'grotões'.

To test the first hypothesis, I verified whether competitors in the same municipality presented distinct government programs. Where this was the case, it was assumed that there is programmatic competition in these locations, corroborating the primary hypothesis of this study. It is not possible to conclude the reasons for this difference, however. This could be related to a specific long-term agenda on the part of parties and candidates, or it could simply represent a strategy to obtain the maximum number of votes. Considering that electoral competition is structured from a unified perspective (ADAMS, MERRILL III and GROFMAN, 2005) - from programmatic and non-programmatic components - it was not possible to infer the extent to which programmatic disputes are effective or determinant in a

\footnotetext{
${ }^{3}$ The selection of municipalities was based on the MHDI ranking provided in the Atlas of Human Development in Brazil. All municipalities classified as having a very low HHDI score in 2010 were included in the analysis. This list is available at <http://www.atlasBrazil.org.br/2013/pt/ranking>.

${ }^{4}$ As Law 12,034/2009 requires that proposals be registered at the same time that candidacy requests are made, all the documents presented by the mayoral candidates were presented, independent of acceptance or posterior rejection.
} 
wider context. If the first hypothesis is corroborated, the second hypothesis postulating that programmatic differences are aligned according to party will be tested, in line with the issue ownership perspective discussed above.

Note that text analysis techniques require some prior preparation of the documents (GRIMMER and STEWART, 2013). Therefore, for this study, all of the encoding and file formats were standardized; word order was disregarded (bag of words); accents, numbers, punctuation, words containing unnecessary content, such as articles, prepositions and conjunctions were removed from the text, as well as words that do not appear in at least $05 \%$ of the documents, independent of frequency. To avoid similar words being counted separately, reducing the frequency of a theme, the stemming 5 process was used to remove affixes from the words, reducing them to their stem form. These processes resulted in a term-document matrix (tdm) in which each document ' $i$ ' represents a vector that counts the frequency with which each single stem (S) occurs, $S_{i}=S_{i 1}, S_{i 2}, \ldots, S_{i n}$.

\section{The data}

The aim of this study is to investigate programmatic competition where it is least likely to be found: in Brazil's 'grotões', which were identified with reference to their MHDI scores. As can be seen in Table 01, these locations are concentrated in the country's North and Northeast regions and their populations are between 5,000 and just over 50,000. In 2012, the average number of mayoral candidates in these municipalities was 2.68, spread across 20 parties. In 2016, the average number of candidates increased to 3.06 , spread across 24 parties.

As Law 12,034/2009 does not specify any required format for these documents, it can be assumed that if candidates simply wanted to fulfill the legal requirements they would not be concerned about writing long documents or detailing specific proposals. This is not what the number of words in the programs presented by candidates in 2012 and 2016 suggests, however. In the first election, less than $10 \%$ of the documents contained just one sheet, or around

\footnotetext{
${ }^{5}$ To exemplify this process, words such as 'work', 'worker' and 'workers' were all considered to be 'work'.
} 
200 words (Table 02). In 2016, the programs were even larger, with a larger number of words in $10 \%$ of the documents than for the previous election.

Table 01. Profile of municipalities and mayoral candidates

\begin{tabular}{|c|c|c|c|c|}
\hline \multirow[b]{2}{*}{ Municipality } & \multirow[b]{2}{*}{ MHDI } & \multirow[b]{2}{*}{ Population } & \multicolumn{2}{|c|}{ Candidacies } \\
\hline & & & 2012 & 2016 \\
\hline Afuá (PA) & 0.489 & 35,042 & PMDB, PP, PT & PT, PSD \\
\hline Amajari (RR) & 0.484 & 21,939 & PR, PPS & PR, PP, PMDB, PSC \\
\hline Anajás (PA) & 0.484 & 24,759 & PSD, PMDB, PP & PSDB, PMDB, PMB, PSD \\
\hline Assunção do Piauí (PI) & 0.499 & 7,503 & PMDB, PSD, PT & PDT, PSD \\
\hline Atalaia do Norte (AM) & 0.450 & 15,153 & PSD, PSOL, PDT & PSDB, PMDB, PDT, PT \\
\hline Bagre (PA) & 0.471 & 23,864 & PR, PSD, PMDB & PT, PRB*, PP, PSD, PMDB \\
\hline Betânia do Piauí (PI) & 0.489 & 6,015 & PSB, PSD, PDT & PP, PDT \\
\hline Cachoeira do Piriá (PA) & 0.473 & 26,484 & PSD, PTB*, PMDB & PTB, PR, PSC \\
\hline Caxingó (PI) & 0.488 & 5,039 & PSB, PT & PP, PT, PMDB \\
\hline Chaves (PA) & 0.453 & 21,005 & PSDB, PMDB & PSDB, PR, PMDB \\
\hline Cocal (PI) & 0.497 & 26,036 & PP, PSDB & PRP, PMDB, PSDB \\
\hline Cocal dos Alves (PI) & 0.498 & 5,572 & PSB, PT & PDT, PT \\
\hline Fernando Falcão (MA) & 0.443 & 9,241 & PMDB, PHS & PDT, PSDB \\
\hline Inhapi (AL) & 0.484 & 17,898 & PT, PMN & DEM, PMDB, PT \\
\hline Ipixuna (AM) & 0.481 & 22,254 & PSD, PCdoB & PROS, PSDB, PR \\
\hline Ipixuna do Pará (PA) & 0.489 & 51,309 & $\begin{array}{l}\text { PSOL, PSDB, PV, } \\
\text { PT }\end{array}$ & PMDB, PT, PEN, PSC \\
\hline Itamarati (AM) & 0.477 & 8,038 & PMDB, PRB & PMDB, DEM, PSDB \\
\hline Itapicuru (BA) & 0.486 & 32,261 & PDT, PSB & PSC, PPL, PSD, PCdoB \\
\hline $\begin{array}{l}\text { Jenipapo dos Vieiras } \\
\text { (MA) }\end{array}$ & 0.490 & 15,440 & PV, PTB & PSDB, PPS, PTB \\
\hline Jordão (AC) & 0.469 & 6,577 & $\begin{array}{l}\text { PCdoB, PMDB*, } \\
\text { PSDB }\end{array}$ & PCdoB, PMDB, PSDB \\
\hline Manari (PE) & 0.487 & 18,083 & PSB, PSDB & PSD, PSDB \\
\hline Maraã (AM) & 0.498 & 17,528 & PMDB, PSD, DEM & PMDB, SD, PSDB, PSD \\
\hline Marajá do Sena (MA) & 0.452 & 8,051 & PT, PMN, PRB & PROS, PCdoB \\
\hline Melgaço (PA) & 0.418 & 24,808 & PP, PMDB, PSDB & PRP, PPS, PSDB \\
\hline Olivença (AL) & 0.493 & 11,047 & PRP, PP, PPS* & PPS, PSD \\
\hline Pauini (AM) & 0.496 & 18,166 & PDT, PMDB, DEM* & $\begin{array}{l}\text { PTB, PMDB, PSB, PROS, } \\
\text { PSD }\end{array}$ \\
\hline Portel (PA) & 0.483 & 52,172 & $\begin{array}{l}\text { PSC, PDT*, PMDB, } \\
\text { PP, PSD, PSDB }\end{array}$ & PSC, PMDB, PTC \\
\hline $\begin{array}{l}\text { Santa Isabel do Rio } \\
\text { Negro (AM) }\end{array}$ & 0.479 & 18,146 & PTB, PDT, PSD & PMDB, PSD, PROS \\
\hline $\begin{array}{l}\text { Santo Antônio do Içá } \\
\text { (AM) }\end{array}$ & 0.490 & 24,481 & PMDB, PT, DEM & PSD, PROS, PMN \\
\hline $\begin{array}{l}\text { São Francisco de Assis } \\
\text { do Piauí (PI) }\end{array}$ & 0.485 & 5,567 & PT, PMDB & PT, PMDB, PP \\
\hline Satubinha (MA) & 0.493 & 11,990 & PV, PMDB & PV, PCdoB \\
\hline Uiramutã (RR) & 0.453 & 8,374 & PT, PV, PSDC & PT, PDT, PP, SD, REDE \\
\hline
\end{tabular}

Source: IBGE, 2017 and TSE, 2018. Notes: *Candidacies that did not register government programs. 
Table 02. Distribution of number of words per set of programs in deciles

\begin{tabular}{ccc}
\hline & 2012 & 2016 \\
\hline $0 \%$ & 123 & 120 \\
$10 \%$ & 372 & 606 \\
$20 \%$ & 596 & 951 \\
$30 \%$ & 732 & 1128 \\
$40 \%$ & 888 & 1415 \\
$50 \%$ & 1046 & 1708 \\
$60 \%$ & 1456 & 2120 \\
$70 \%$ & 1917 & 2345 \\
$80 \%$ & 2906 & 3398 \\
$90 \%$ & 4416 & 3934 \\
$100 \%$ & 9426 & 13112 \\
\hline
\end{tabular}

Source: Author's own data.

On average, the platforms registered in 2012 contained 1,869 words. The PT candidate for Ipixuna do Pará registered the largest program, containing 9,426 words, and the PSDC candidate for Uiramutã registered that smallest, containing 123 words. Graph 01, which shows that the variation per and between parties is very high and there is no party or ideological divide ${ }^{6}$. The PT, for example, provided the largest program, but also one of the smallest. The same oscillation was identified for the parties with the largest number of candidates, the PMDB and the PSD. One of the PCdoB candidates, considered more ideological, registered a program containing five times the number of words of that registered by the second candidate. The two PSOL candidates used fewer words than the average.

In 2016, the average size of the 98 programs analyzed increased to 2,164 words. The smallest of these was registered by the PROS in Santa Isabel do Rio Negro, containing 120 words, and the smallest was registered by the PSD in Maraã, containing 13,112 . Similarly to 2012 , it was impossible to identify any party or ideological divide in relation to the size of the documents presented, as indicated in

\footnotetext{
${ }^{6}$ There is a statistically significant relationship between the size of an alliance and the number of words. Each party included in an alliance increases the number of words in the government program by 164 . This may indicate that there is collaboration or a bargaining process in the writing of these programs, but this is beyond the scope of this study.
} 
Graph 02. These examples demonstrate a concern in the development of government programs, especially considering that the law obliging the registration of documents does not specify the format.

Graph 01. Dispersion of number of words per program per party (2012)

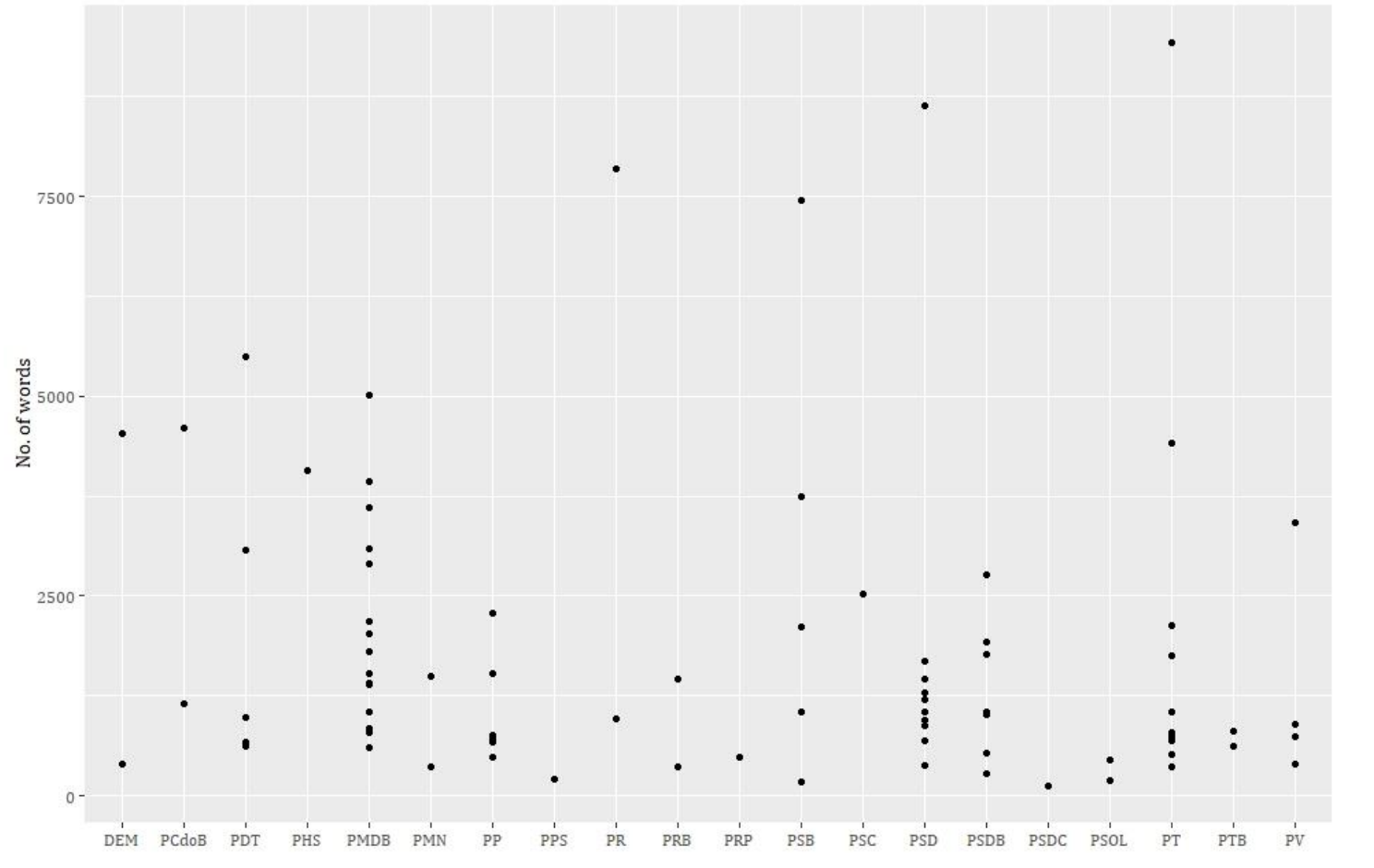

Source: Author's own data.

But what about the content of these policy platforms? Was there a difference between the programs provided by the mayoral candidates in the least developed municipalities? One way to answer this question is to observe the frequency of the words used by the candidates. It was assumed that if the words used in government programs are distinct, their proposals must also be distinct. The degree of differentiation enabled candidates to be distributed on a scale indicating how much they differed in terms of their programs.

For example, the graphs in Figure 01 indicate the positions of the candidates in four of the 32 municipalities analyzed for the 2012 elections, chosen at random. In each case, there is divergence between the programs presented by the candidates. The largest of these was for Uiramutã, where the PSDC appears in position -1.8 and the PV appears in position 1.5. In the other municipalities, this distance varies between 2.0 and 1.5. It is interesting to note that 
when there is a third party, it tends to take on a more centrist position, which is in agreement with spatial voting models.

Graph 02. Dispersion of number of words per program per party (2016)

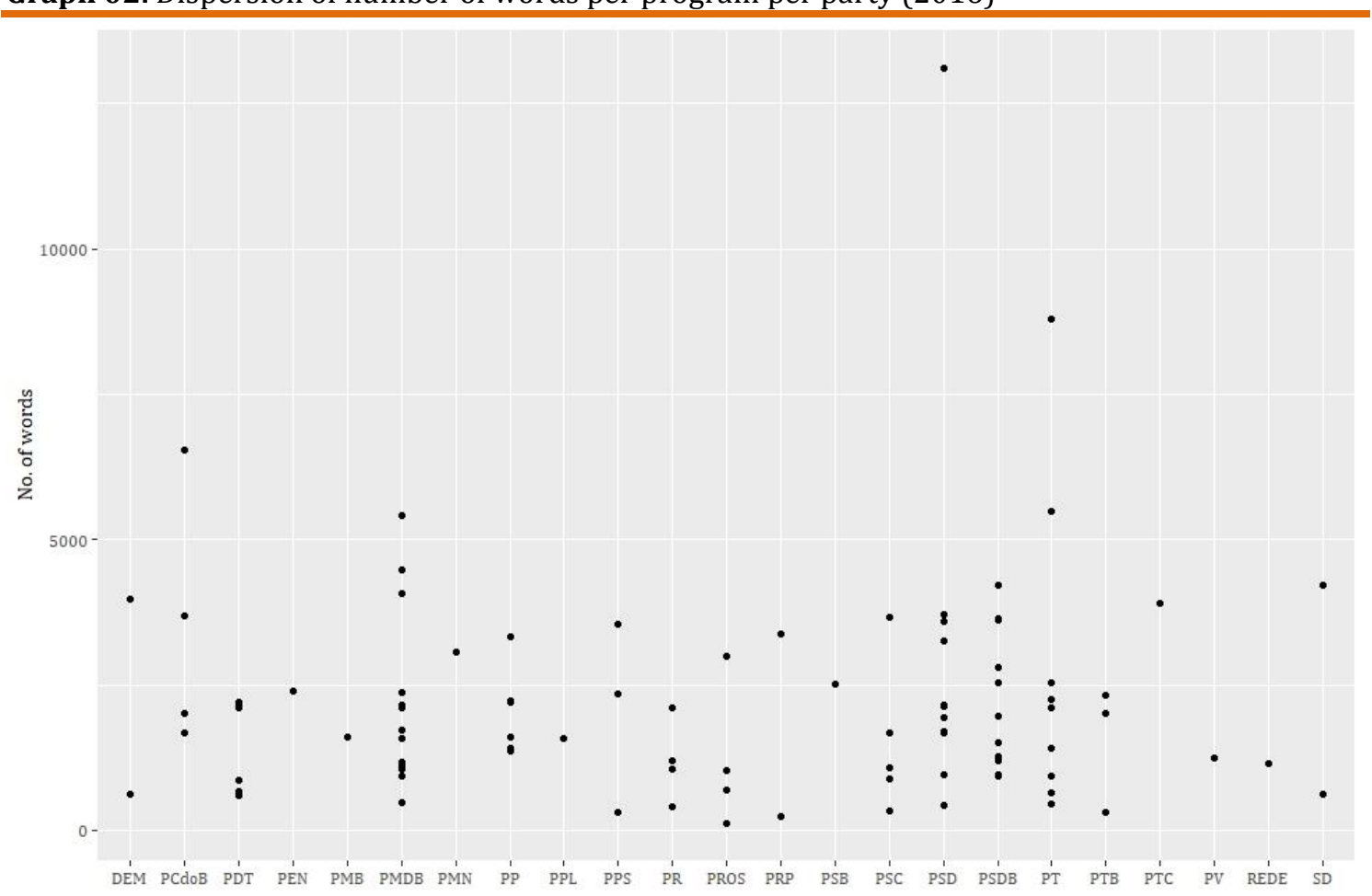

Source: Author's own data.

Considering that each of the 64 disputes analyzed comprises one case, the results cannot be presented individually in this way. For this reason, the calculations of absolute distance and the variance between positions were used as a measure of competition. For the former, the difference between the maximum and minimum positions was measured for each election - with this alone enabling the divergence between the programs to be demonstrated and indicating if there is competition in this dimension. Independent of how this is presented, it can be assumed that there is a programmatic dimension in all the municipalities studied for the two elections. This means that at least two candidates presented different proposals for public policy in the same municipality. This observation can be proven by calculating the difference between the maximum and minimum special positions for each location. Observing the distribution of these, one notes that there were no cases where this was equal to ' 0 '. 
Figure 01. Position of candidates per municipality (2012)

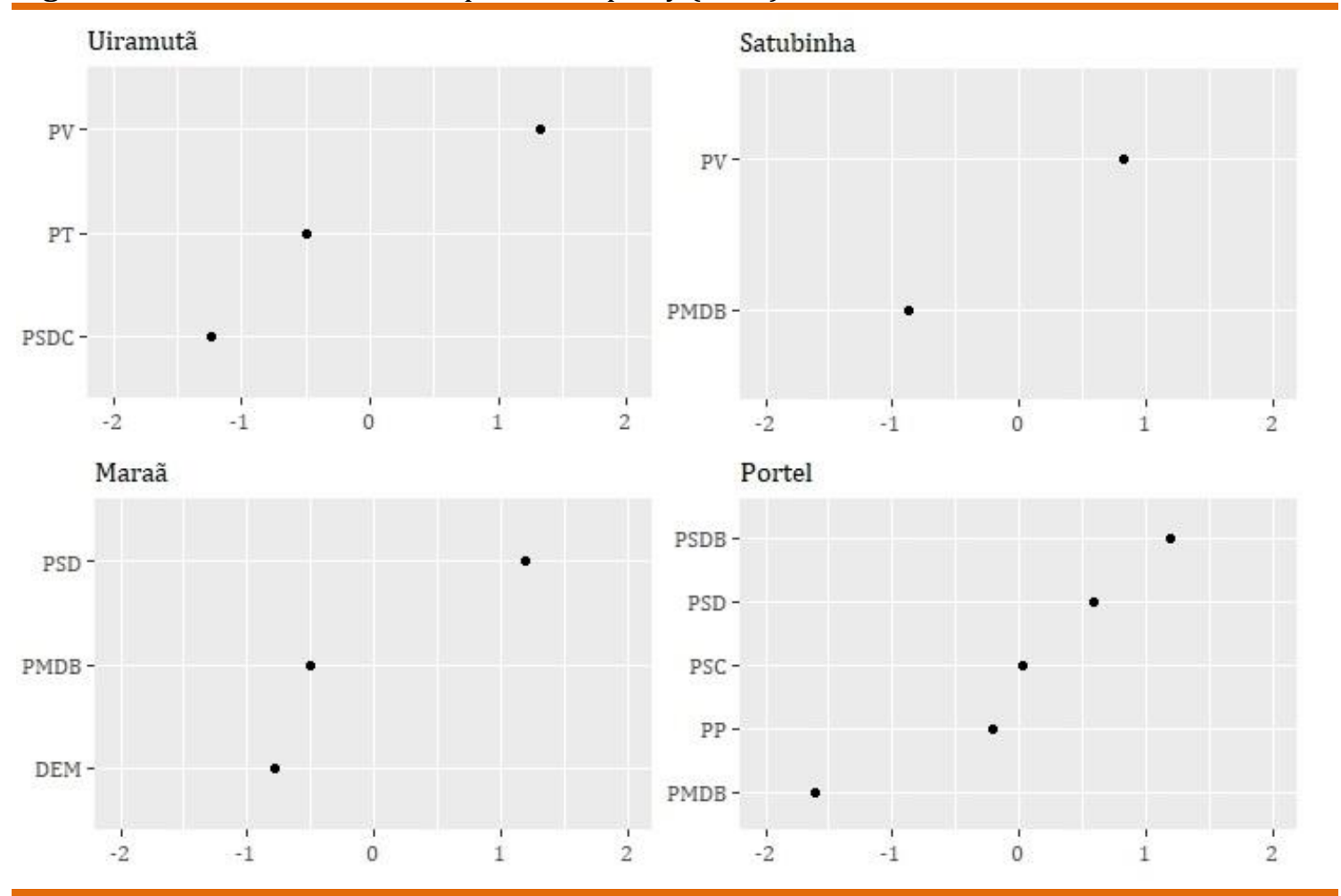

Source: Author's own data.

In 2012, most programmatic competition involved distances of between 1.5 and 2.0, with a smaller group distributed between 2.0 and 2.5 (Graph 03). In 2016, this pattern inverted, and most municipalities presented greater programmatic competition, with values between 2.0 and 2.5, while a smaller set of locations was positioned between 1.5 and 2.0. These figures indicate that the divergence between the platforms was larger for more cases in 2016 than in 2012. It is important to note that the values of the distances do not have, within the scope of this study, any specific substantive meaning. It is simply of interest to note that these were greater than ' 0 ' in every case, confirming the presence of programmatic space as an actual strategy during the elections in question.

However, this analysis may be less precise in cases with more than two competitors, as it considers the minimum and maximum positions and does not take intermediate positions into account. In analytical terms, this means that large distances can be inferred between candidates in municipalities presenting three candidates, where two of these have very similar positions and the other's is very different. In this case, even if there actually is a programmatic dimension, this would 
exist at shorter distances than those determined by the above analysis, when all documents are taking into consideration. Therefore, it is also important to evaluate the variance between the positions extracted from the programs and the average point on the political spectrum. It follows that that this provides a more relative analysis of each case.

Graph 03. Absolute distance between government program positions per municipality (2012-2016)

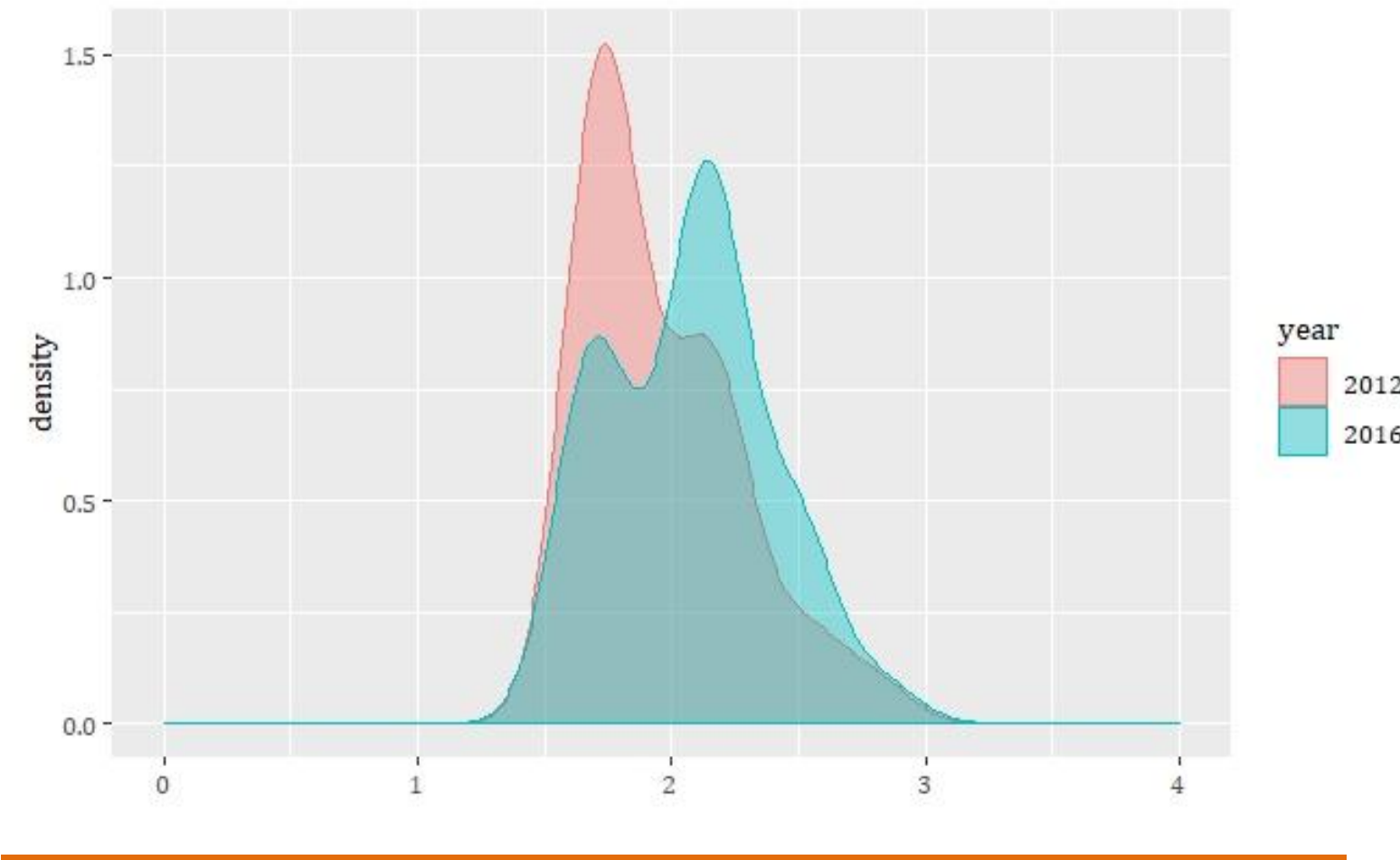

Source: Author's own data.

As presented in Graph 04, the variance of the candidates' positions generated from the analysis of their government programs also enables us to assume that there is a programmatic dimension involved. The distances are now reduced, as they are not calculated from the maximum and minimum values. This analysis also demonstrates that programs differed less in 2012 than they did in 2016. In the first election, there is just one concentration of cases, with a variance between 1.0 and 1.5. In the following election, a lower group of municipalities is distributed around this value, while most are closer to 1.5. In 2016, there are also more locations where the variance of programmatic competition is over 1.5 , some even reaching values over 2.0. 
Both the analysis of absolute distances between the positions of government programs in each municipality and the variance demonstrate the existence of programmatic competition, even in the less developed municipalities of Brazil in the two election years considered. This is because mayoral candidates present different government programs to their opponents in all the cases examined, as postulated above. However, the model used presents some limitations. Firstly, the divergence identified refers to the use of words that do not have any substantial meaning a priori. Secondly, this analysis is developed comparatively. In other words, the position of one program is attributed as a function of the words used by the other candidates. As each case represents a different election in a different year, the data presented demonstrates that if a particular municipality has an absolute distance or variance between program positions of 1.2, for example, this is lower than the divergence between programs in an election whose value is 2.0 . What this analysis cannot provide is the actual degree of difference between these two scenarios. Only programs in the same election can be meaningfully compared. Therefore, it is important to take a more qualitative view of representative cases.

Graph 04. Variance of positions of government programs per municipality (2012-2016)

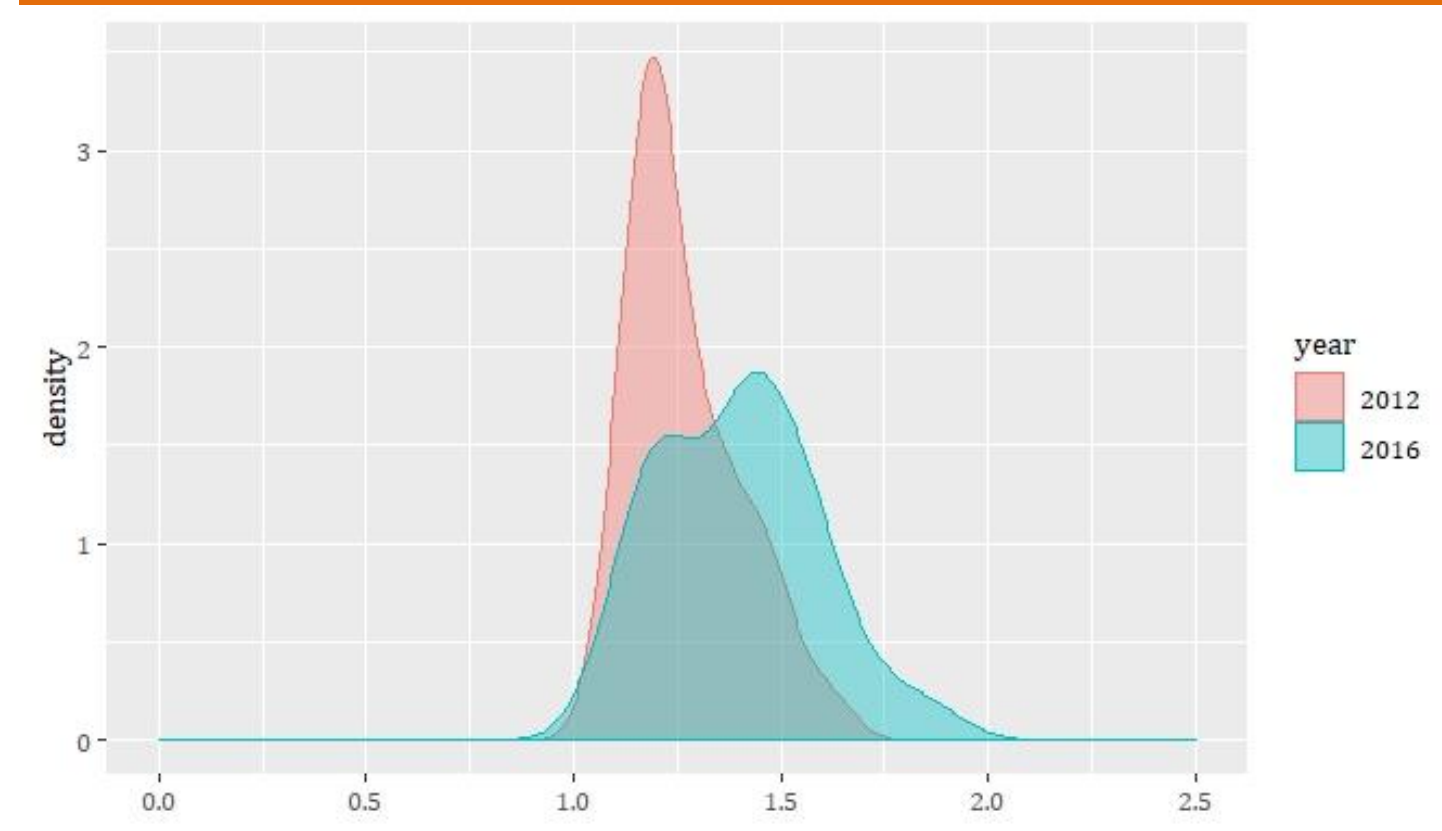

Source: Author's own data. 
Considering cases with the highest absolute distances ${ }^{7}$, the municipality with the most or least programmatic competition can be verified in qualitative terms. The candidates that differed the least in both elections were located in Manari (PE) in 2012, with an absolute distance of 1.62 between the candidates for the PSB and the PSDB. Replacing the common terms in the two documents with \#\#\#\#, the remaining divergence involves the specification of agricultural production and themes such as vulnerability, homophobia and race by the PSB candidate, and Fome Zero, certain health policies and related details by the PSDB candidate.

On the other hand, the largest absolute distance of all of the disputes analyzed was verified for the municipality of Pauini (AM) in 2016. At this location, the size of the documents located at the extremes of the programmatic spectrum was distinct, which explains the divergence of 2.82. The PMDB candidate presented a shorter program than that of the PSB candidate, and most of the terms used in the former were contained in the latter, although the contrary was not the case. Analysis of the proposals shows that only the PMDB candidate used the terms 'ice', 'pisciculturist', 'child prostitution', 'INSS' and 'artesian well'. In addition, many names appeared in this platform, which may correspond to neighborhoods, schools or health centers, for example. The divergence of the larger program presented by the PSB candidate can be observed through the inclusion of themes such as 'poverty', 'rubber', agricultural, cattle-raising and sporting policies, nepotism and cultural and regional issues, which are not included in the other candidate's program.

The data demonstrate that government programs were a component in both the 2012 and 2016 elections. This means that the mayoral candidates in the municipalities with the lowest MHDI scores distinguished themselves programmatically, adopting different words and proposals in their programs. The fact that the candidates differed programmatically does not necessarily mean that this distinction is aligned along partisan lines, which represents a separate empirical question. To determine whether a specific party positions itself in a similar way on the programmatic spectrum, an analysis must be performed on all candidates together as though they were competing in the same municipality. This enables a

\footnotetext{
${ }^{7}$ The measurement of absolute distance was chosen due to the ease in comparing the terms in just two programs, as proposed.
} 
comparison to be made between the government programs to identify how similar they

are. This is just a preliminary analysis, but it seems to be the most suitable alternative

when using a comparative method such as Wordfish.

Chart 01. Comparison between programs in Manari (PE) (2012)*

\begin{tabular}{|c|c|}
\hline PSB & PSDB* \\
\hline 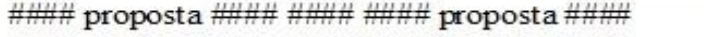 & 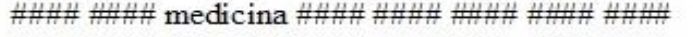 \\
\hline 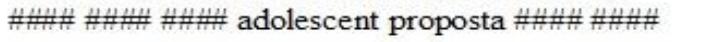 & 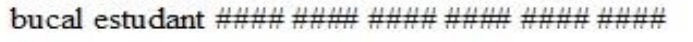 \\
\hline 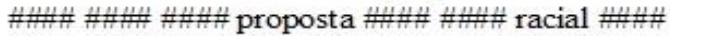 & 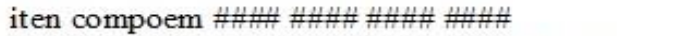 \\
\hline 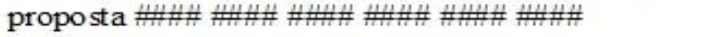 & interrompido \#\#\# \#\#\#\#\#\#\# contemplar \#\#\# \\
\hline proposta \#\#\# \#\#\# \#\#\# proposta \#\#\#\# povo & dispo \#\#\#\#\#\#\# excelent instal\#\#\#\#\#\#\# hospit \\
\hline \#\#\#\# libertar povo livrar \#\#\# permanencia & 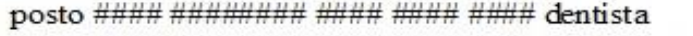 \\
\hline \#\#\#\#\#\# esforco \#\#\# gradual \#\#\# aprimorar & \#\#\#\# \#\#\# \#\#\# \#\#\# fisioterapeuta \#\#\#\# \#\#\# \\
\hline 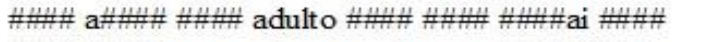 & \#\#\#\# necessario \#\#\#\# \#\#\#\# \#\#\# \#\#\# \#\#\# \#\#\# \\
\hline \#\#\# \#\#\# prazo entrega aprimorar \#\#\#\# \#\#\# & emergenci periodo noturno finai \#\#\# feriado \\
\hline 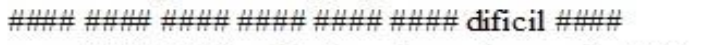 & $\# \# \#$ reconhecido agrest pernambuc\#\#\# fornec \\
\hline povo \#\#\#\#\#\# conhecimento equipamento \#\#\# & \#\#\# financeiro \#\#\# oculo lent \#\#\#\#\#\# \\
\hline 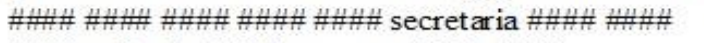 & medicina \#\#\# garantindo \#\#\# mamografia \\
\hline \#\#\# aplicado \#\#\#\# contratar \#\#\#\#\#\#\# \# & ultrasson necessario \#\#\#\# cancer mama colo utero \\
\hline psicopedagogo \#\#\#\#\#\#\#\#\#\# trabalhador \#\#\# & 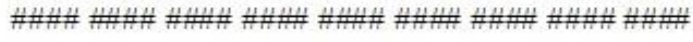 \\
\hline 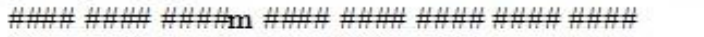 & 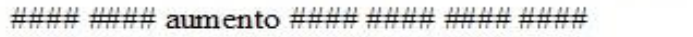 \\
\hline 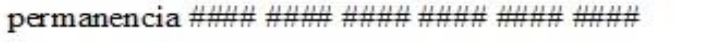 & 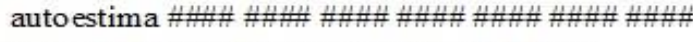 \\
\hline 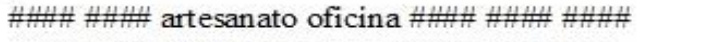 & 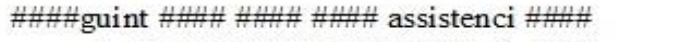 \\
\hline 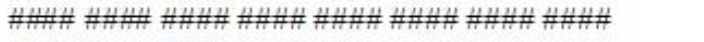 & 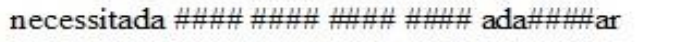 \\
\hline priorizando \#\#\#\#\#\#\# vulnerabilidade \#\#\#\#\#\# & 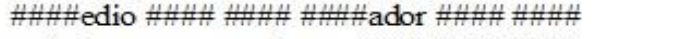 \\
\hline ambulancia povoado \#\#\# estrutura \#\#\# & 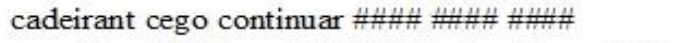 \\
\hline 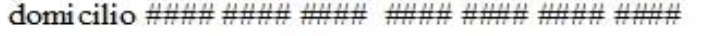 & respeitam \#\#\#izam \#\#\#\#\#\#\# pluralismo \#\#\#\# \\
\hline doenca \#\# transmissivei & 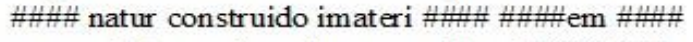 \\
\hline \#\#\#\#\#\#\# exam \#\#\#\#fico & memoria transmissao heranca naturai \\
\hline 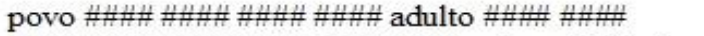 & 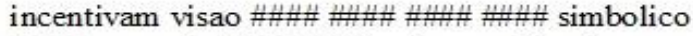 \\
\hline \#\#\# \#\#\#\# \#\#\#\# \#\#\#\# \#\#\#\# \#\#\#\# vulnerabilidade & \#\#\#\# ancorado \#\#\# \#\#\#logica participativa \\
\hline 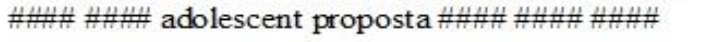 & 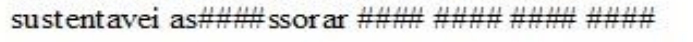 \\
\hline 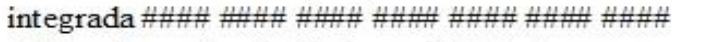 & 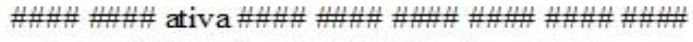 \\
\hline \#\#\# enfocando prioritariament \#\#\# atencao & 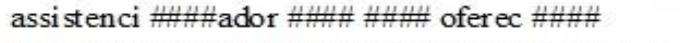 \\
\hline 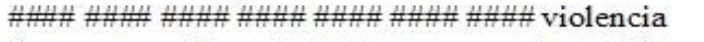 & \#\#\#\#ismo \#\#\# bolsa \#\#\#\# fome zero expansao \\
\hline decorrent negligencia maus trato homofobia & 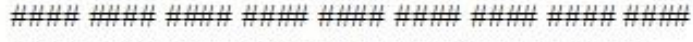 \\
\hline 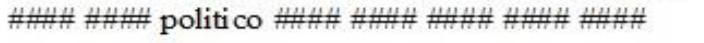 & 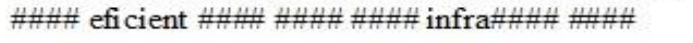 \\
\hline povo \#\#\#\# \#\#\#\# racial \#\#\#\#\#\#\# proposta \#\#\#\# & 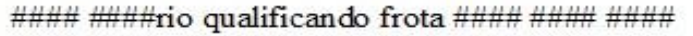 \\
\hline \#\#\# \#\#\# \#\#\#\# \#\#\#\# \#\#\#\# relacionada \#\#\#\# & 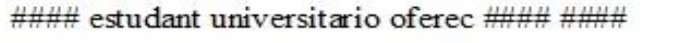 \\
\hline humano milho feijao sorgo capim revitalizar & 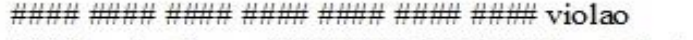 \\
\hline peren pinha mandioca caju arborizar zona \#\#\#\# & 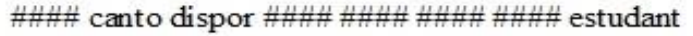 \\
\hline \#\#\# planta frutifera capacitar \#\#\# melhor & 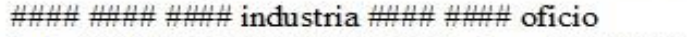 \\
\hline aproveitamento umbu \#\#\#\#\#\# conceicao \#\#\#\# & 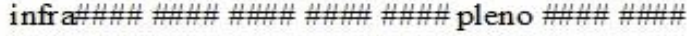 \\
\hline 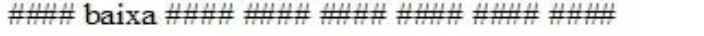 & 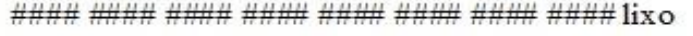 \\
\hline \#\#\# implementar \#\#\#\# habitacion compativel & 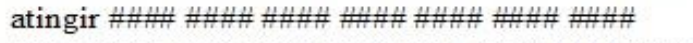 \\
\hline 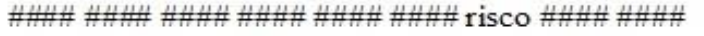 & \#\#\# \\
\hline campanha conscientiz\#\#\#\# risco causado trafego & 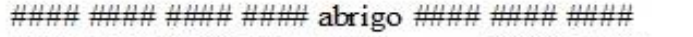 \\
\hline animai solto \#\#\# rodovia reestruturar & 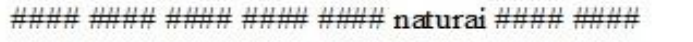 \\
\hline 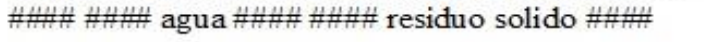 & continuar incrementando alimento \#\#\# \\
\hline 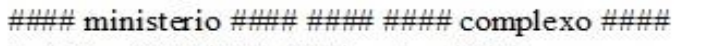 & 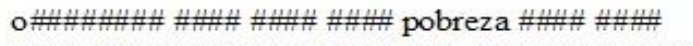 \\
\hline 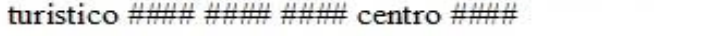 & 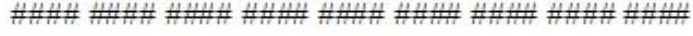 \\
\hline & $\begin{array}{l}\text { \#\#\# parqu \#\#\#\# \#\#\#\# \#\#\#\# \#\#\#\# \#\#\#\# \#\#\#\# } \\
\text { patrol }\end{array}$ \\
\hline
\end{tabular}

Source: Author's own data. Notes: *Excerpts qualitatively selected from the greatest similarity criteria. 
Another possibility would be to group the position identified for each municipality according to party. However, considering that the position of candidate ' $i$ ' in municipality ' $k$ ' is a function of the position of competitor ' $j$ ' in the same municipality, grouping all of the positions would not provide a correct analysis, as the reference point varies between municipalities. Another option would be to analyze all the programs from a single party, but considering that these may present similar proposals, this method would tend only to highlight the differences between them, hindering the investigation into their alignment or consistency. Therefore, the analysis in this study compares all the programs of all parties for each election and enables both the similarities and differences between the programs to be identified ${ }^{8}$.

This analysis results in a classification of government platforms according to party across the programmatic spectrum. In order to confirm party alignment, parties' proposals should occupy the same point on the scale, or at least be situated on the same side in relation to the midpoint (zero). This is confirmed through the location of the entire boxplot - which if situated on just one pole, indicates alignment - and the non-centralized position of the median. Independent of the programs' distribution, the location of the median on one of the poles of the programmatic spectrum is interpreted as determining partial alignment, as this indicates the close positioning of at least half of the platforms registered by a determined party. Parties with just one government program in the 'corpus' of this study were disregarded, including the PHS, PPS, PRP, PSC and PSDC in 2012 and the PEN, PMB, PMN, PPL, PSB, PTC, PV and REDE in 2016.

Generally speaking, the party alignment analysis for the 2012 elections indicates the programs being spread across the positive and negative poles of the political spectrum, as shown in Graph 05 . Of the 20 parties analyzed, just the PCdoB, PSD, PSDB, PSOL, PTB, PV, and to a lesser extent the PP, demonstrated alignment between proposals. However, taking into consideration that five parties have just one program, this represents almost half of all the parties. For the parties that did not demonstrate alignment through location of the entire boxplot, the position of the median indicated partial alignment for the PRB, PT, PR, PSB and PDT. The medians for

\footnotetext{
${ }^{8}$ These statements are based on sensitivity tests carried out along the study. However, this method still needs to be refined for the analysis of party alignment presented in this study.
} 
the PMDB, PMN, and DEM were very close to the midpoint of the programmatic spectrum, demonstrating an absence of alignment between their proposals.

Graph 05. Distribution of proposals according to party in all municipalities (2012)

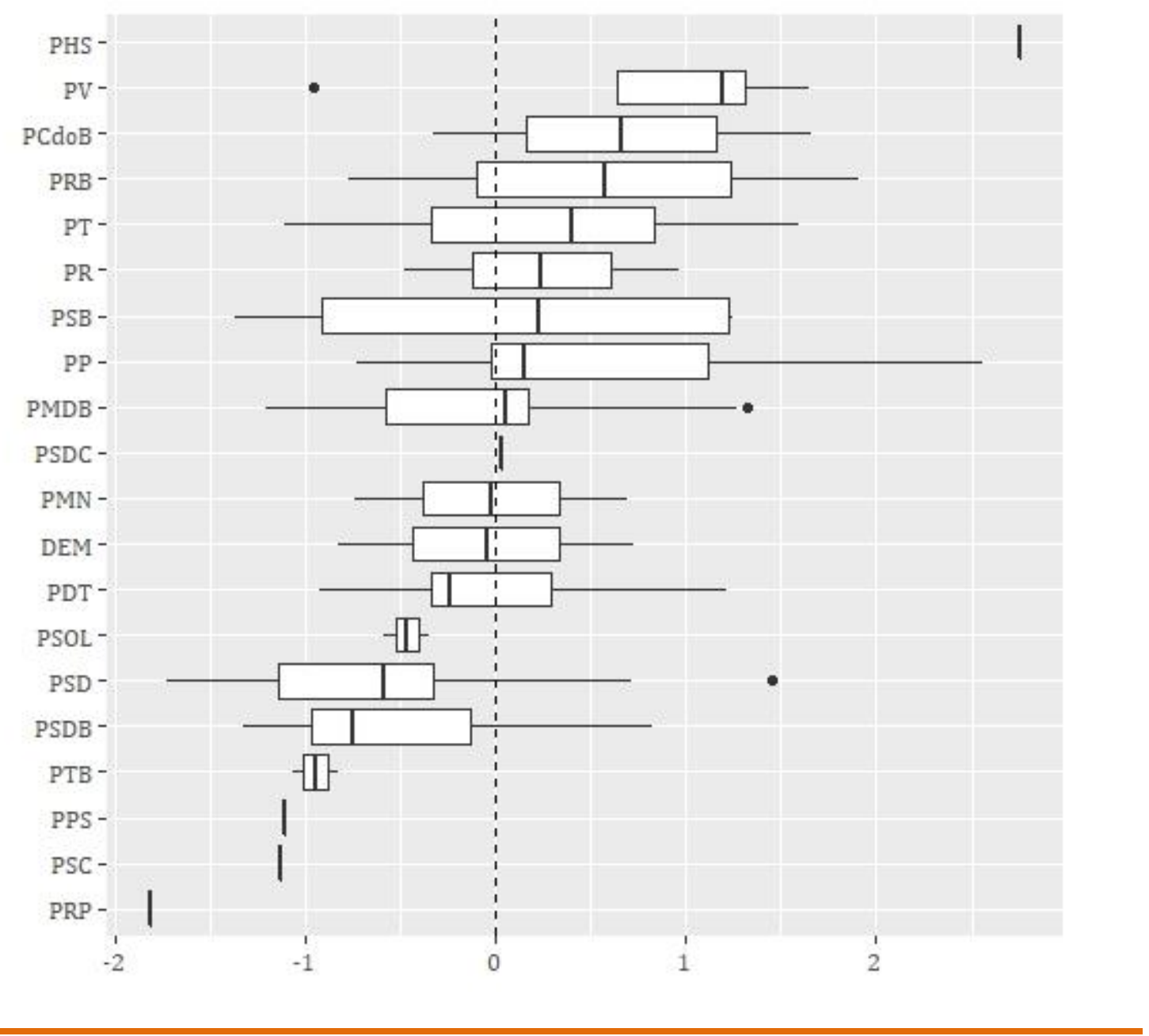

Source: Author's own data.

Observing the pole on which the parties are aligned, there does not appear to be any relationship between the similarity between proposals and party ideology ${ }^{9}$, with the PV, PCdoB and PP on the positive pole and the PSOL, PSD, PSDB and PTB on the negative pole. It is important to note that this model attributes positive and negative positions randomly, without any substantive meaning. Therefore, just because the PTB and PSDB are on the negative pole, this does not indicate dissociation with ideology. However, the amount of terms in common with

${ }^{9}$ See Power and Rodrigues-Silveira (2019) for an analysis into ideology in municipalities from the perspective of the electorate. 
the PSOL makes this ideological dissociation clear. The same can be said for the positive pole.

This configuration changes for the 2016 elections, as shown in Graph 06. In this election, there seems to be more alignment within parties. This is the case for the PP, PRP, PDT, PT and PR, which are concentrated on the positive pole, and the PCdoB on the negative pole. However, there are more parties with a more disperse distribution, but with a polarized median, as is the case for the PMDB. In 2012, this party had a more centrist position, but it appears in 2016 with partial alignment on the positive pole. The opposite is true for the PSD and PSDB, which presented partyaligned proposals in 2012 but not in 2016. Once again, the alignment of parties does not seem to be structured ideologically, as the PP, PRP, PDT, PT and PR present proposals which show greater internal similarity than do those of the other parties.

Graph 06. Distribution of proposals according to party for all municipalities (2016)

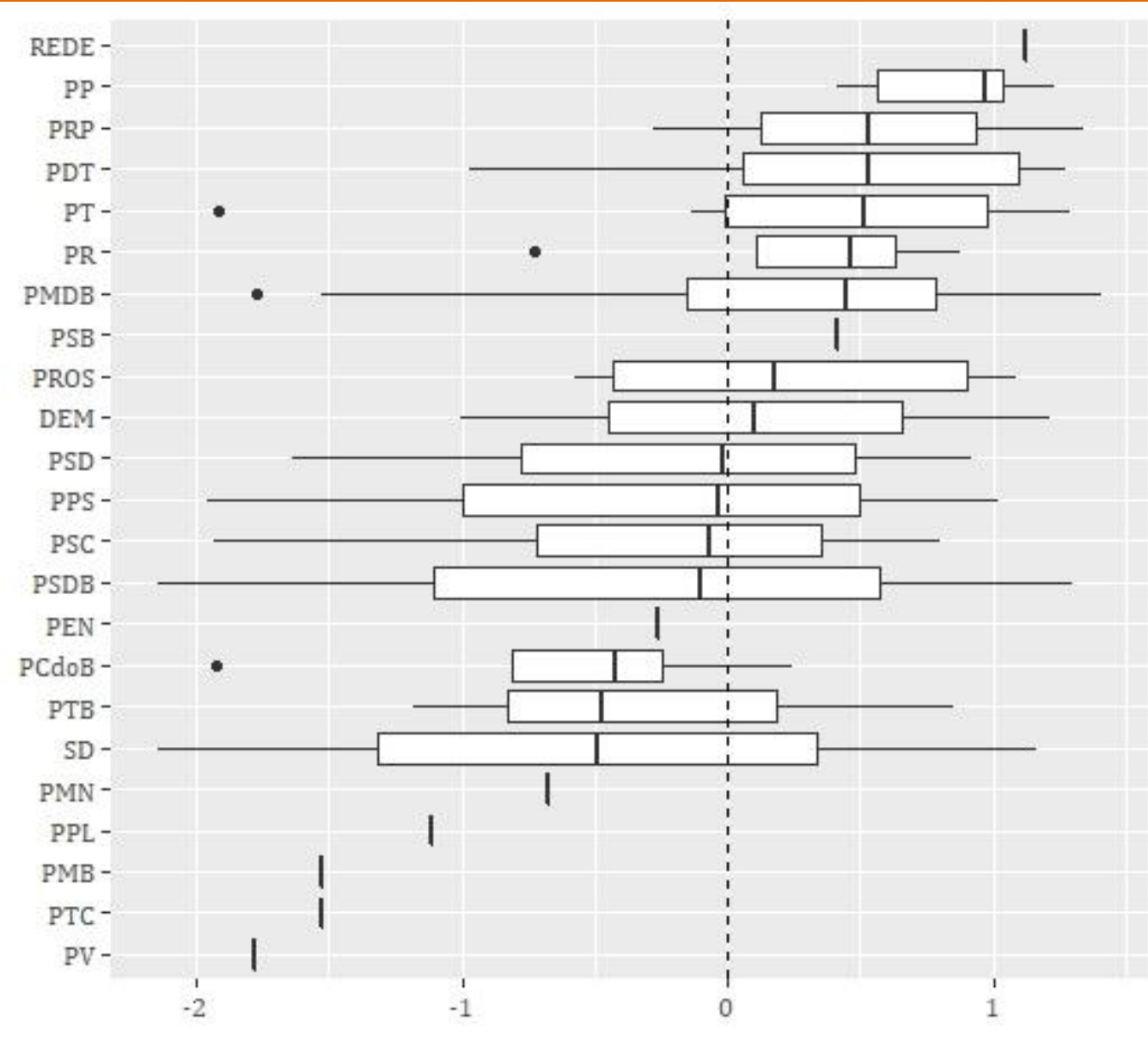


With regards to party alignment, it is important to note that the positive and negative poles do not necessarily have any substantive meaning in the analysis performed in this study. Moreover, it should be considered that Wordfish is a relational method, meaning that documents' positions are given in relation to other documents. Therefore, although the configuration of party positions may have changed from 2012 to 2016 in terms of program content, this does not automatically mean that parties realigned in terms of the policies they offered. Changes in the number and type of parties presented as well as other contextual elements could have caused this. It should also be emphasized that some party associations presented similar programs in different municipalities. Therefore, to some extent political party can be considered an indicator of the nature of public policy proposals offered by mayoral candidates in Brazil's 'grotões'.

\section{Final considerations}

Although the classical Downsian proximity model of party competition involves a 'programmatic paradox', implying convergence as opposed to competition between parties in terms of their government programs, alternative studies demonstrate the importance of this component. This applies to models such as the 'party activism model' (ALDRICH, 1983), the 'directional model' (RABINOWITZ and MAcDONALD, 1989) and the 'discount model' (GROFMAN, 1985) or 'political motivation model' (ALESINA, 1988; WITTMAN, 1983). However, the principal basis of this study is 'salience theory of party competition', according to which parties also compete through the emphasis they place on determined issues (BUDGE and FARLIE, 1983; COLOMER and PUGLISI, 2005; SIO and WEBER, 2014; ROBERTSON, 1976). This leads to two principal developments that refute Downs (1957a, 1957b): disputes are multidimensional, enabling parties to highlight the issues they 'possess' or that favor them the most; and as these issues are strategically leveraged to maximize votes by shaping preferences as an intrinsic component of the electoral contest.

Despite this, government programs of elections has been neglected in Brazil, where there is assumed to be a predominance of weak parties, personalism and clientalism (AMES, 2003; HAGOPIAN, 1996; MAINWARING, 1991, 1999). This scenario attains its apex in the country's so-called 'grotões' - its smaller, less 
developed municipalities where the electorate is seeking to meet its most basic needs, which reinforces clientelistic relationships with candidates (AMES, 2003; ANDRADE and SANTOS, 2004; AVELAR and WALTER, 2008; LEAL, 1975; SCHWARTZMAN, 1975).

However, an analysis of mayoral candidates' programs in these municipalities demonstrates that these candidates differ programmatically from one another and that this distinction presents a certain degree of consistency within parties. To a certain extent, these results contest the recurring diagnosis in the literature that the Brazilian political scene comprises weak or underdeveloped parties, in which the open-list proportional representation system is responsible for the prominence of clientelism and the personal vote.

It is important to highlight that these findings do not demonstrate that clientelism does not exist in Brazil or that municipal elections are exclusively programmatic. Neither can these results infer the programmatic motivation of candidates and parties. It cannot be confirmed whether different policies are proposed out of preference, because this agrees with their ideology or due to any other factor. After all, programs may simply be the tools used to win the highest number of votes. What these findings can confirm, however, is that candidates and parties are indeed using this tool, even in Brazil's 'grotões', where these are least likely to be found.

Regarding to the size of the programs, it was verified that there was no ideological divide beyond high dispersion. Therefore, the same party presented platforms with a larger number of words in one municipality and a shorter number of words in another. However, evaluating average word counts in the documents 1,890 and eight respectively - candidates appear to have an interest in differentiating themselves programmatically, as the law that makes these obligatory does not provide any specific format.

Programmatic difference between competitors was identified, especially when the words used by them in their government programs were analyzed. Therefore, platform content positioned parties in different ways on the spatial scale, attributing larger or smaller distances between all of the candidates in all the municipalities studied. In addition to the differences between programs, it was 
identified that candidates in the same party presented some alignment between their proposals. When the platforms of the same party were analyzed, many of these were positioned on similar points of the scale. Although this did not apply to all parties, this was clear in the case of the PCdoB and the PP for both the 2012 and 2016 elections. Other parties presented alignment between proposals in just one election, including the PV, PSOL, PSD, PSDB and PTB in 2012 and the PRP, PDT, PT, PR in 2016. This alignment seems to suggest some degree of coordination and party organization, even on a local level.

In summary, these findings demonstrate that even in Brazil's most isolated and least developed municipalities, there are incentives for candidates to promote programmatically different proposals, and that there is some party alignment between these. New tools such as government programs were used to empirically test some important perspectives on Brazil's political parties and electoral competition, and it was demonstrated that a close-up and more thorough approach to these municipalities provides a more complex understanding of their electoral realities.

Translated by Fraser Robinson

Submitted on October 16, 2018

Accepted on May 06, 2019

\section{References}

ADAMS, James F.; MERRILL III, Samuel, and GROFMAN, Bernard (2005), A unified theory of party competition: a cross-national analysis spatial and behavioral factors. Cambridge: Cambridge University Press. 332 pp..

ALDRICH, John H. (1983), A Downsian spatial model with party activism. American Political Science Review. Vol. 77, № 04, pp. 974-990.

ALESINA, Alberto (1988), Credibility and policy convergence in a two-party system with rational voters. American Economic Review. Vol. 78, № 04, pp. 796-805.

ANDRADE, Luís Aureliano Gama and SANTOS, Manoel Leonardo (2004), 0 município na política brazileira: revisitando coronelismo, enxada e voto. In: Sistema político brasileiro: uma introdução. Edited by AVELAR, Lúcia and CINTRA, Antônio Octávio. Rio de Janeiro/São Paulo: Fundação Konrad Adenauer/Fundação Editora Unesp. pp. 205-221.

AVELAR, Lúcia and WALTER, Maria Inez Machado Telles (2008), Lentas mudanças: o voto e a política tradicional. Opinião Pública. Vol. 14, № 01, pp. 96-122. 
AVELINO FILHO, George (1994), Clientelismo e política no Brazil: revisitando velhos problemas. Novos Estudos CEBRAP. Vol. 38, № 01, pp. 225-240.

AMES, Barry (2003), Os entraves da democracia no Brazil. Rio de Janeiro: Editora FGV. 409 pp..

BABIRESKI, Flávia Roberta (2014), As diferenças entre a direita do Brazil, Chile e Uruguai: análise dos programas e manifestos partidários. Paraná Eleitoral. Vol. 03, № 01, pp. 171-198.

BUDGE, Ian (1987), The internal analysis of election programmes. In: Ideology, strategy and party change: spatial analysis of post-war election programmes in 19 democracies. Edited by BUDGE, Ian; ROBERTSON, David, and HEARL, Derek. Cambridge: Cambridge University Press. pp. 15-38.

BUDGE, Ian and FARLIE, Dennis J. (1983), Explaining and predicting elections: issue effects and party strategies in twenty-three democracies. London/Boston: Unwin Hyman. 226 pp..

CAMPBELL, Angus; CONVERSE, Philip E.; MILLER, Warren E., and STOKES, Donald E. (1960), The American voter. Chicago:University of Chicago Press. 576 pp..

COLOMER, Josep and PUGLISI, Riccardo (2005) Cleavages, issues and parties: a critical overview of the literature. European Political Science. Vol. 04, № 04, pp. 502-520.

DINIZ, Eli (1982), Voto e máquina política: patronagem e clientelismo no Rio de Janeiro. Rio de Janeiro: Paz e Terra. 228 pp..

DOWNS, Anthony (1957a), An economic theory of political action in a democracy. The Journal of Political Economy. Vol. 65, № 02, pp. 135-150.

DOWNS, Anthony (1957b), An economic theory of democracy. New York: Harper \& Row Publishers. 310 pp.

FIGUEIREDO, Argelina Cheibub and LIMONGI, Fernando (2002), Incentivos eleitorais, parties e política orçamentária. Dados. Vol. 45, № 02, pp. 303-344.

GAY, Robert (1998), Rethinking clientelism: demands, discourses and practices in contemporary Brazil. Revista Europea De Estudios Latinoamericanos Y Del Caribe/European Review Of Latin American And Caribbean Studies. Vol. 65, pp. 07-24.

GRIMMER, Justin and STEWART, Brandon M. (2013), Text as data: the promise and pitfalls of automatic content analysis methods for political texts. Political Analysis. Vol. 21, № 03, pp. 267-297. 
GROFMAN, Bernard (2004), Downs and two-party convergence. Annual Review of Political Science. Vol. 07, pp. 25-46.

GROFMAN, Bernard (1985), The neglected role of the status quo in models of issue voting. The Journal of Politics. Vol. 47, № 01, pp. 230-237.

HAGOPIAN, Frances (1996), Traditional politics and regime change in Brazil. Cambridge: Cambridge University Press. 342 pp..

HAGOPIAN, Frances; GERVASONI, Carlos, and MORAES, Juan Andrés (2008), From patronage to program: the emergence of party-oriented legislators in Brazil. Comparative Political Studies. Vol. 42, № 03, pp. 360-391.

HUNTER, Wendy and POWER, Timothy J. (2008), Rewarding Lula: executive power, social policy, and the Brazilian elections of 2006. Latin American Politics and Society. Vol. 49, № 01, pp. 01-30.

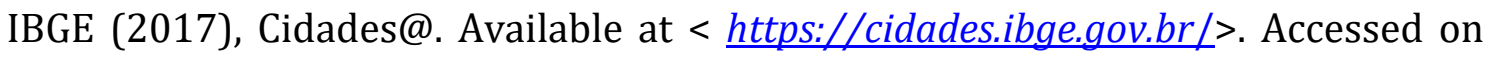
August, 14, 2019.

JORGE, Vladimyr; SILVA, Mayra; FARIA, Alessandra, and FERREIRA, Ana Rita (2018), Análise dos programas eleitorais dos candidatos a presidente em 2014: o posicionamento ideológico do PT e do PSDB. Revista de Sociologia e Política. Vol. 26, № 67, pp. 01-20.

KERBAUY, Maria Teresa Miceli (2000), A morte dos coronéis: política interiorana e poder local. Araraquara/São Paulo: Unesp/Cultura Acadêmica. 156 pp..

KITSCHELT, Herbert; HAWKINS, Kirk A.; LUNA, Juan Pablo; ROSAS, Guilermo, and ZECHMEISTER, Elizabeth J. (2010), Latin America party systems. Cambridge: Cambridge University Press. 416 pp..

LEAL, Victor Nunes (1975), Coronelismo, enxada e voto. São Paulo: Editora AlfaÔmega. 280 pp..

LIMONGI, Fernando (2012), Eleições e democracia no Brazil: Victor Nunes Leal e a transição de 1945. Dados. Vol. 55, № 01, pp. 37-69.

MAINWARING, Scott P. (1999), Rethinking party systems in the third Wave of democratization: the case of Brazil. Stanford: Stanford University Press. 412 pp..

MAINWARING, Scott P. (1992-93), Brazilian party underdevelopment in comparative perspective. Political Science Quaterly. Vol. 107, № 04, pp. 677-707.

MAINWARING, Scott P. (1991), Políticos, partidos e sistemas eleitorais: o Brazil numa perspectiva comparada. Novos Estudos CEBRAP. № 29, pp. 34-58. 
OLIVEIRA, Augusto Neftali Corte de (2011), Os discursos programáticos dos partidos políticos na América Latina: identidade de classe e política econômica. Mediações. Vol. 16, № 01, pp. 201-221.

POWER, Timothy J. and RODRIGUES-SILVEIRA, Rodrigo (2019), Mapping ideological preferences in Brazilian elections, 1994-2018: a municipal-level study. Brazilian Political Science Review. Vol. 13, № 01, pp. 01-27.

RABINOWITZ, George and MACDONALD, Elaine (1989), A directional theory of issue voting. American Political Science Review. Vol. 83, № 01, pp. 93-121.

ROBERTSON, David Bruce (1976), A theory of party competition. New York: Wiley. 210 pp..

SAMUELS, David (1997), Determinantes do voto partidário em sistemas eleitorais centrados no candidato: evidências sobre o Brasil. Dados. Vol. 40, № 03, pp. 0811.

SCHWARTZMAN, Simon (1975), São Paulo e o Estado Nacional. São Paulo: Difusão Europeia do Livro. 190 pp..

SIO, Lorenzo de and WEBER, Till (2014), Issue yield: a model of party strategy in multidimensional space. American Political Science Review. Vol. 108, № 04, pp. 870-885.

SLAPIN, Jonathan B. and PROKSCH, Sven-Oliver (2008), A scaling model for estimating time-series party positions from texts. American Journal of Political Science. Vol. 52, № 03, pp. 705-722.

STOKES, Donald E. (1963), Spatial models of party competition. American Political Science Review. Vol. 57, № 02, pp. 368-377.

TAROUCO, Gabriela da Silva (2011), Brazilian parties according to their manifestos: political identity and programmatic emphases. Brazilian Political Science Review. Vol. 05, № 01, pp. 54-76.

TAROUCO, Gabriela da Silva and MADEIRA, Rafael Machado (2013), Partidos, programas e o debate sobre esquerda e direita no Brasil. Revista de Sociologia e Política. Vol. 21, № 45, pp.149-165.

TSE (2018), Divugacand: Divulgação de candidaturas e contas. Available at $<$ http://divulgacandcontas.tse.jus.br/divulga/\#/>. Accessed on August, 08, 2019.

WITTMAN, Donald (1983), Candidate motivation: a synthesis of alternative theories. American Political Science Review. Vol. 77, № 01, pp. 142-157. 